\title{
Венчурне фінансування оборонної промисловості: досвід США у вимірі України
}

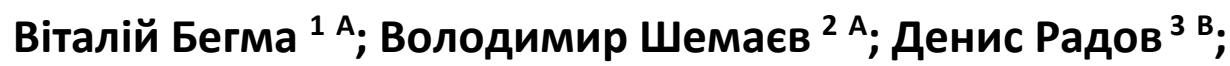 \\ Поліна Толок 4 с \\ А Національний інститут стратегічних досліджень, м. Київ, Україна

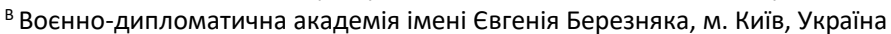 \\ с Центральний науково-дослідний інститут ОВТ ЗСУ, м. Київ, Україна
}

Received: August 15, 2021 | Revised: August 24, 2021 | Accepted: August 31, 2021

JEL Classification: D78, G24, H56, O51

DOI: $10.33445 /$ sds.2021.11.4.17

\begin{abstract}
Анотація
У статті проаналізовано досвід США у використанні венчурного капіталу при фінансуванні робіт щодо розвитку сучасних зразків озброєння та військової техніки та технологій військового та подвійного призначення. Розкрито сутність, особливості та вплив венчурних інвестицій на інноваційний розвиток оборонної промисловості, ї̈ внесок у економічний поступ держави в цілому.

Виявлено основні проблеми та тенденції венчурного інвестування в оборонній сфері. Визначено можливі перспективні сфери ефективного використання венчурного капіталу для оборонної промисловості України.
\end{abstract}

Ключові слова: венчур, капітал, інвестування, фонди.

\section{Постановка проблеми}

Україна визначила курс на європейську інтеграцію, розвиток співробітництва 3 державами НАТО та Європейського Союзу. Зусилля країн - членів цих альянсів спрямовані на підтримку реформ i трансформацію оборонного сектору нашої держави. Постачання окремих зразків озброєння та військової техніки, а саме, обладнання, засобів зв'язку та захисту, приладів нічного бачення, окремих зразків автомобільної техніки типу "Hummer", радіолокаційних станцій AN/TPQ-49, протитанкових комплексів "Javelin" тощо - все це вже сьогодні позитивно впливає на підвищення ефективності застосування підрозділів Збройних сил України.

Разом із тим, окрім завдань постачання озброєнь та військової техніки, перед державою стоїть питання створення в Україні нових технологій та виробничих потужностей для створення сучасного озброєння, що неможливо без надходження у сферу оборонної промисловості належних інвестицій. I одним з напрямків залучення додаткових коштів на розвиток вітчизняного ОПК може бути використання венчурного капіталу.

Упродовж останніх десятиліть венчурний капітал став потужним фінансовим двигуном для нових технологій і галузей, які змінюють світ. Він заохочує інновації та надає підприємцям інструменти, необхідні для розробки і просування своїх ідей. Метою використання венчурного капіталу $\epsilon$ інвестування в різні стартапи - знаючи, що більшість із них зазнає невдачі, але сподіваючись, що хоча б один великий успіх із

\footnotetext{
${ }^{1}$ Corresponding author: д.е.н., професор, провідний науковий співробітник, e-mail: vitnik1964@ukr.net, ORCID: 0000-0002-0556-1785

${ }^{2}$ д.військ.н., професор, головний консультант, e-mail: shemayeva@ukr.net, ORCID: 0000-0003-1629-6689

${ }^{3}$ кандидат економічних наук, e-mail: naukadradov@gmail.com, ORCID: 0000-0001-8139-4563

${ }^{4}$ Заслужений економіст України, к.е.н., старший науковий співробітник, e-mail: tolok100@meta.ua, ORCID: 0000-0002-2481-8152
} 
надлишком компенсує ці втрати. Саме тому зазначений бізнес завжди був зосереджений на технологічних компаніях, які пропонують найбільший потенціал для швидкого зростання і збільшення прибутку.

Багатьма економістами венчурні інвестиції розглядаються як найважливіший стратегічний фактор підвищення конкурентоспроможності виробництва шляхом упровадження інновацій, пов'язаного з великою різноманітністю ризиків [1]. Таким чином, венчурний капітал виступає одним з головних каталізаторів інноваційного розвитку.

Оскільки розвиток Збройних сили України в сучасних умовах все більше залежать від передових технологій, актуальності набуває питання про використання венчурного капіталу для технологічних розробок в інтересах Збройних сил України (ЗСУ). Найбільш показовим $є$ приклад використання венчурного капіталу армією Сполучених Штатів Америки.

\section{Аналіз останніх досліджень та публікацій}

Проблеми використання венчурного капіталу у фінансуванні іноваційної діяльності в Україні досліджувалися такими авторами, як: М. М. Поляк, Г. Ю. Яковець, О. М. Ковальова, О. М. Петрук, С. З. Мошенський, А. М. Поручник, Л. Л. Антонюк, В. В. Клименко, Т. О. Бутурлакіна, В. В. Завацька [2-8]. Вони розглядали питання, пов'язані 3 венчурним

фінансуванням різних галузей економіки, не лише в Україні, а й західноєвропейських країнах та США.

\begin{tabular}{llr}
\multicolumn{1}{c}{ Проте } & недостатньо & розглянутим \\
залишається & питання & використання \\
венчурного & капіталу для фінансування \\
оборонної & сфери, що й обумовлює \\
актуальність обраної теми статті.
\end{tabular}

\section{Постановка завдання}

Мета статті: розкриття особливостей використання венчурного капіталу для

фінансування оборонної промисловості України на прикладі успішного досвіду США.

\section{Виклад основного матеріалу}

США мають довготривалий досвід щодо використання венчурного капіталу В національній науці і промисловості, а також сприяння у реалізації високотехнологічних стартапів, що швидко розвиваються. Першою компанією, що його започаткувала, стала Bessemer Ventures. Вона була утворена в 1911 році як сімейна фірма Генрі Фіппсамолодшого, співзасновника Carnegie Steel. Сьогодні ця компанія управляє більш як 5 млрд дол. США й інвестує у глобальні проєкти, маючи офіси в Сан-Франциско, Редвуд-Сіті, Нью-Йорку, Бостоні, Ізраїлі та Індії). Незважаючи на ці глибокі корені, венчурна індустрія США інституціоналізувалася як клас активів далеко не відразу. Такі провідні гравці на рику, як компанії Sequoia Capital, KPCB, Charles River Ventures i NEA, були засновані лише в 1970-х роках, а Accel Partners - в 1980-х. Тільки з середини 1990-х років, галузь суттєво зросла (в 1995 році була заснована Benchmark Capital), перетворивши економіку США на одну 3 найбільш динамічних економік світу [9].

Так, у 2020 році лише венчурні інвестиції в США, навіть попри вбивчу для світової економіки пандемію коронавірусу, досягнули рекордних 130 млрд дол. США, що на 14\% більше, ніж було у 2019 році. А в 2018 році американські стартапи отримали від інвесторів загалом 122 млрд дол. США. За даними досліджень, проведених аналітиками PwC та СB Insights (це міжнародна мережа компаній, які відслідковують світові тенденції ринку інвестицій та діяльність венчурних організацій і стартапів), до числа найбільш перспективних напрямків для розвитку інвестування разом із біологічними, медичними та IT-технологіями де частка американської економіки складає 25\% від 
світової, увійшли й космічні та оборонні, а також розробка штучного інтелекту [10].

Маючи величезну кількість професійних інвесторів, готових інвестувати чималі кошти у високоризиковані технологічні бізнеси США перетворились на світовий центр високотехнологічного підприємництва [11].

Сьогодні у США вже працює близько 1200 венчурних фондів, більша частина з яких сконцентрована у Кремнієвій долині штату Каліфорнія. Серед компаній, які на початку своєї роботи покладалися на венчурне фінансування, - SpaceX, Palantir Technologies, Amazon, Apple i Google, Intel, DEC, Microsoft, Sun Microsystems, FedEx, Genentech, Netscape, Facebook.

Основними центрами тяжіння стартапів та інвесторів є міста: Бостон (штат Массачусетс), Нью-Йорк (штат Нью-Йорк), Остін (штат Техас), Денвер (штат Колорадо), ЛосАнджелес (штат Каліфорнія) та Сіетл (штат Вашингтон). Однією з причин такої високої активності у різних частинах США $\epsilon$ концентрація потужних інноваційних ідей навколо великих університетів, випускники яких зазвичай і створюють ці стартапи. Так, у Каліфорнії це університети Стенфорд і Берклі, у Бостоні - Массачусетський технологічний інститут, в Остіні - Техаський університет, в Лос-Анджелесі - Каліфорнійський університет тощо.

Дослідження ефективності використання венчурного капіталу в США підтвердили позитивну кореляцію між венчурним капіталом та інноваціями на фірмах, що його використовують, відмічається, при цьому, високий рівень патентної активності [12], а також великі інвестиції в дослідження та розробки, які ці фірми роблять у порівнянні 3 іншими компаніями [13].

Створені на американському технологічному ринку фонди венчурного капіталу мають вирішальне значення для “перекачування" капіталу В невеликі високотехнологічні компанії, що потребують грошових вливань. При цьому, частина інвесторів венчурного капіталу визнає, що багато з цих підприємств зазнають невдачі, але у разі, коли вони стають успішні, можуть отримати величезну віддачу від своїх інвестицій.

Розглянемо особливості використання венчурного капіталу в інтересах збройних сил США. Як і будь-яка армія, збройні сили США зазнають труднощів із балансуванням своїх потреб у нових технологіях і наявних ресурсах для їхньої розробки, і стикаються 3 проблемою пошуку більш досконалих методів розробки нових технологій, необхідних у військовій справі.

Більша частина технічних інновацій у країні відбувається у комерційному секторі, що робить доступ до них військових як ніколи, важливим. Використовуючи модель венчурного фінансування, армія може здійснювати доступ до результатів НДДКР приватного сектору, який постійно збільшує відсоток витрат як на прикладні, так i на фундаментальні дослідження.

Венчурні компанії обороннопромислового комплексу США свого часу виникли так само природно, як і приватні військові компанії, коли на початку 1990-х років почалася трансформація збройних сил. Масові скорочення в армії, економія військового бюджету - все це призвело до появи таких структур як венчурні компанії та фонди злиттів i поглинань. Завдяки їм оборонно-промисловий комплекс США не лише пережив істотне скорочення державних витрат, а й уникнув втрат у забезпеченні обороноздатності держави. Досвід венчурного інвестування таких фірм, як OnPoint Technologies, Veritas Capital Management, Arlington Capital Partners, Behrman Capital, Carlyle Group, DC Capital Partners, Paladin Capital Group, In-Q-Tel та інших дозволив фактично створити новий сектор стартап-проектів в галузях високотехнологічної оборонної промисловості.

На думку керівників військового відомства США, саме венчурний капітал може більше надати підприємцям шанс підтримувати високотехнологічні проєкти та спонукати 
невеликі технологічні компанії працювати над оборонними замовленнями. Так, міністр оборони США (2017 - 2019 роки) Джеймс Меттіс заявляв, що він шукає можливості підвищення боєздатності збройних сил за допомогою приватних технологічних компаній [14], було втричі збільшено фінансування експериментального підрозділу з оборонних інновацій (DIUx) у складі міністерства оборони США, якому було доручено створити стартапи для забезпечення технологічної переваги американської армії. DIUx виділив 100 млн. дол. США у якості державних контрактів на 45 проєктів. Завдяки їм приватні інвестори вклали у ці компанії ще 2 млрд. дол. США, демонструючи довіру до нових технологій. Це дозволило армійському керівництву США заявити про початок переведення своїх солдат із “індустріальної епохи" в “епоху інформаційну" і однією з рушійних сил цього поступу стала розробка програмного забезпечення для збройних сил [15].

Наприкінці 2020 року Пентагон повідомив про розроблене за участі венчурних інвестицій на своїй “фабриці програмного забезпечення для створення військових ITрішень" в Остінському окружному коледжі при Техаському університеті. Зазначене програмне забезпечення використовувалося для націлювання систем озброєння, які пройшли успішне випробування у військових підрозділах на Близькому Сході, де постійно базуються 60-70 тисяч військовослужбовців США.

Підвищений інтерес до інвестицій в оборонну галузь не обмежується тільки інвесторами зі США. Так, у 2019 році Агентство зв'язку та інформації НАТО інвестувало 3 млрд. євро у технології, пов'язані зі зміцненням кібернетичної, повітряної та протиповітряної оборони.

Водночас аналіз, зроблений корпорацією RAND (американською некомерційною організацією, яка виконує функції стратегічного дослідницького центру, працюючого на замовлення уряду США, їхніх збройних сил і пов'язаних із ними організацій), показує, що не тільки материнський фонд венчурного капіталу армії допоможе оживити дослідження і розробки НДДКР в оборонній промисловості, але й армія повинна фінансувати частину свого технологічного розвитку через залучення приватного венчурного капіталу.

Залучення зовнішніх ресурсів від співінвесторів дозволило б розширити власні можливості для фінансування НДДКР. Окрім того, дохід від інвестицій у венчурний фонд армії може бути використаний для реінвестування в нові технології [16].

Згідно з дослідженням RAND, навіть великі корпорації використовують венчурні фонди. Мова про Xerox, Microsoft i Lucent Technologies. Незважаючи на те, що ці компанії володіють значними можливостями для фінансування НДДКР, вони усвідомлюють переваги венчурного капіталу і тепер використовують його для розробки технологій для свого бізнесу [17].

Отже, 3 одного боку, армійський венчурний капітал може поліпшити доступ військових до комерційних технологій, вирішуючи проблеми розробок $\mathrm{i}$ застосування нових технологій в армії, а 3 іншого - виступати в ролі посередника, який розуміє і задовольняє потреби ділових i технологічних спільнот.

Основні переваги використання венчурного капіталу в інтересах збройних сил, на думку дослідників RAND, полягають у наступному:

\section{- венчурний капітал може} використовувати невійськові ресурси. Сьогодні більшість досліджень в інтересах армії США проводяться виключно за рахунок ресурсів армії. Припускаючи, що армійський фонд інвестує в технології з комерційним потенціалом, він, імовірно, зможе залучити значні спільні інвестиції. Таким чином, армія може використовувати власні ресурси для досліджень і розробок, щоб прискорити розвиток ключових технологій, а також 
продовжувати інвестувати в широкий спектр нових ідей;

$\begin{array}{lrr}\text { - венчурний } & \text { капітал } & \text { забезпечує } \\ \text { повернення } & \text { інвестицій. } & \text { Більшість }\end{array}$

технологій, придатних для інвестування через фонд венчурного капіталу армії, матимуть довгостроковий комерційний потенціал. Використовуючи модель венчурного капіталу для початкових інвестицій у нові технології, армія зможе заробляти на окупності інвестицій у міру зростання їх комерційного ринку;

- венчурний капітал допомагає "підняти" цілі галузі. За свою історію венчурний капітал став джерелом стартових грошей для багатьох країн, що розвиваються. Оскільки велика частина НДДКР в даний час проводиться в комерційному секторі, багато технології завтрашнього дня розробляються 3 внеском військових. Створивши власний венчурний фонд, армія також зможе отримати вплив на галузі, що розвиваються.

Визнаючи необхідність задіяти сектор комерційних технологій, керівництво армії планує розширити співпрацю 3 розробниками комерційних технологій. Проте розвиток співпраці між науководослідними підрозділами армії і розробниками комерційних технологій ускладнюють традиційні методи укладання контрактів в армії. Армійські представники, яким часто не вистачає підготовки, ресурсів і повноважень для проведення маркетингових досліджень, схильні покладатися на традиційну базу підрядників для задоволення потреб уряду. 3 іншого боку, комерційно орієнтовані компанії порівнюють невеликий розмір армійського ринку 3 тягарем, пов'язаним з громіздкими урядовими правилами закупівель, негнучкими вимогами до нагляду i побоюваннями 3 приводу інтелектуальної власності. I дуже часто ці проблеми $€$ нездоланними для багатьох потенційних інвесторів.

У відповідь на проблеми, пов'язані 3 традиційними державними контрактами, зусилля з реформування системи закупівель призвели до створення нових інструментів контрактів на НДДКР, призначених для забезпечення доступу до комерційного сектору. До них належать «угода про спільні дослідження і розробки» (CRADA), “угода про співпрацю” (СА) та “інші транзакції” (ОT). У той час як ці нові інструменти укладання контрактів вирішують багато з проблем, зазначених вище, успіх армії з ними все ж був невеликий, будучи швидше епізодичним, ніж системним [18].

Водночас, на заваді реформи системи закупівель у збройних силах США стоять дві основні проблеми. По-перше, вона не зорієнтована і не спрямована на розуміння і сприяння потребам і методам роботи приватного бізнесу. Стара традиція продовжує заважати армії працювати за межами своєї штатної бази підрядників. Подруге, керівники приватних американських фірм, задіяних у секторі комерційних технологій, здебільшого скептично ставляться до проведення урядом реформ і не довіряють державним контрактам у цілому.

Подолання цих проблем вимагає діяти швидше і гнучкіше, ніж діючі контрактні організації міністерства оборони, потребує регулярної перепідготовки кадрів і вибудовування нових відносин із комерційним сектором для того, щоби нарешті завоювати довіру приватних клієнтів.

Отже, досвід США у сфері венчурної політики для оборонної промисловості дозволяє дійти висновку, що венчурний капітал, створений для цілей задоволення технологічних потреб оборонної промисловості, може бути зручним та альтернативним шляхом для науководослідної та дослідно-конструкторської діяльності, де усі сторони, які беруть участь у такій угоді, виграють від успіху венчурного капіталу:

- цільова фірма може досягти фінансового успіху; 
- оборонна промисловість може користуватися успіхом інновації;

- комерціалізація інтелектуальної

власності може збільшити податкові

- надходження держави;

- потреби національної безпеки оборонної промисловості можуть бути задоволені.

Таким чином, слід зазначити, що використання моделі венчурного капіталу для розробки передових технологій може значно допомогти армії в досягненні мети реформи системи придбання та закупівель OBT, що полягає в швидкому та спрощеному доступі до передових технологій, яких вона потребує.

В Україні метою провадження інноваційної діяльності у сфері оборонно-промислового комплексу має бути задоволення потреб держави в сучасних високоефективних системах озброєнь, військової та спеціальної техніки відповідно до встановлених нормативів, національних та міжнародних стандартів, а також потреб експорту наукоємної продукції шляхом оновлення та формування нової науково-технологічної бази підприємств та організацій обороннопромислового комплексу за допомогою поєднання ефективного державного управління і ринкових механізмів саморозвитку.

Для досягнення поставленої мети в державі повинні бути відрегульовані рамкові умови розгортання масштабної інноваційної діяльності у сфері оборонно-промислового комплексу, зокрема стосовно забезпечення оптимального балансу ринкових і регуляторних важелів впливу держави на інноваційний розвиток, вдосконалення структури оборонно-промислового комплексу за інноваційною моделлю [19].

Інноваційна діяльність і необхідні заходи щодо їі розвитку в оборонно-промисловому ВисновКИ

Потреби у нових технологіях для збільшення бойового потенціалу Збройних Сил України та обмеженість наявних ресурсів для їхньої розробки, змушують шукати більш досконалі комплексі мають розглядатися з урахуванням таких основних пріоритетів:

адаптація інноваційної інфраструктури у сфері оборонно-промислового комплексу до умов глобалізації та підвищення ії конкурентоспроможності;

створення привабливих умов для творців інновацій, стимулювання інноваційної активності підприємств обороннопромислового комплексу;

переорієнтація інноваційної інфраструктури на ринковий попит і споживача;

системний підхід в управлінні інноваційною діяльністю, інформаційне забезпечення.

Основними шляхами інноваційного розвитку оборонно-промислового комплексу України $\epsilon$ застосування системи прискореного інноваційного розвитку та нової моделі наукового забезпечення інноваційної діяльності у сфері обороннопромислового комплексу; введення в дію нових механізмів фінансування, кредитування та інвестиційного забезпечення оборонно-промислового комплексу тощо [19].

Реформування оборонно-промислового комплексу для активізації інноваційної діяльності має проводиться за принципом створення необхідних умов для впровадження інновацій у виробничі процеси.

Для досягнення цього необхідно створити нову систему фінансового, кредитного та інвестиційного забезпечення обороннопромислового комплексу, а також створити сприятливий інвестиційний клімат для здійснення інвестицій в обороннопромисловий комплекс, зокрема, механізм захисту цих інвестицій із забезпеченням національних інтересів та національної безпеки.

методи залучення додаткових коштів у НДДКР, пов'язаних з оборонними дослідженнями.

Використовуючи модель венчурного фінансування, зСУ змогли 6 вирішити 
проблеми доступу до результатів наукових розробок приватного сектору, який постійно збільшує відсоток витрат як на прикладні, так і на фундаментальні дослідження.

Партнерство власників технологічних компаній із гравцями оборонної промисловості може значно допомогти останній покращити свої можливості щодо інформаційних технологій та інших галузей техніки, де приватний сектор далеко попереду.

\section{Список використаних джерел}

1. Левкович-Маслюк Л. Точка роси // Бизнесжурнал “Компьютерра". URL: http://www.computerra.ru/compunity/femi $\mathrm{da} / 21747 /$

2. Поляк М. М. Сучасний стан та перспективи розвитку венчурного інвестування в Україні / М. М. Поляк // Держава та регіони. Сер. : Економіка та підприємництво. - 2013. - № 5. - С. 113116. URL: http://nbuv.gov.ua/UJRN/drep_ 2013_5_22.

3. Яковець Г. Ю. Напрями удосконалення аналізу венчурної діяльності для прийняття управлінських рішень / Г. Ю. Яковець // Вісник Житомирського державного технологічного університету. Серія : Економічні науки. - 2015. - № 1. C. 63-67. URL: http://nbuv.gov.ua/UJRN/ Vzhdtu_econ_2015_1_11.

4. Ковальова, О. М. Деякі теоретичні та практичні аспекти обґрунтування вибору джерел фінансування підприємства / О.М. Ковальова, Ю. Є. Кітаєва // Проблеми ринку та розвитку регіонів України в XXI ст. : матеріали VII Міжнарод. наук.-практ. Інтернет-конф., м. Одеса, 05-09 груд. 2016 р. - Одеса, 2016. - С. 40-43.

5. Петрук О. М., Мошенський С. 3. Теорія та практика венчурного фінансування: монографія. - Житомир: Рута, 2008. - 248 с.

6. Поручник А. М., Антонюк Л. Л. Венчурний капітал: зарубіжний досвід та проблеми становлення в Україні. - К.: КНЕУ, 2000. $171 \mathrm{c.}$
Проте, пристосовуючи досвід США до українських реалій, слід мати на увазі, що при всій своїй привабливості, венчурне фінансування не $є$ універсальним механізмом. Воно корисне у своїй конкретній «ніші» розвитку інноваційної активності підприємств і не може компенсувати брак коштів із інших джерел для розвитку науково-технічної сфери, у тому числі й фінансування НДДКР для Збройних сил України.
7. Клименко В. В. Венчурное инвестирование: мировой опыт и Украина / Науковий вісник Інституту міжнародних відносин Національного авіаційного університету: економіка, право, політологія, туризм. Том 1. № 1-2. (2012). С. 37-45.

8. Бутурлакіна Т. О., Завацька В. В. Проблеми функціонування венчурного капіталу як джерела фінансування інноваційної діяльності в Україні та шляхи вдосконалення (на прикладі досвіду США) // Глобальні та національні проблеми економіки. Електронне наукове видання Миколаївського національного університету ім. В.О. Сухомлінського. Вип. № 4 (2015). C. 791-784.

9. Venture-backed Startups Will Build the Defense Technology the Free World Needs Right Now Josh Manchester, Jun 13, $2019 \cdot 10$ min read. URL: https://medium.com/@joshmanchester/ven ture-backed-startups-will-build-the-defensetechnology-the-free-world-needs-right-nowd2cefa2b2196

10. Максим Чеботарев. Инвестиции поамерикански: как работают венчурные фонды в США//Forbes Contributor. 28.04.2018 року. URL: http://www.forbes.ru/tehnologii/360888investicii-po-amerikansky-kak-rabotayutvenchurnye-fondy-v-ssha.

11. Venture Capital Funding Report Q4 2020. PwC and CB Insights' Q4 2020 MoneyTree report highlights the latest trends in venture capital funding globally. 13 січня 2021 року. 
URL:http://www.cbinsights.com/research/re port/venture-capital-q4-2020/

12. Samuel Kortum and Josh Lerner, "Does Venture Capital Spur Innovation", Working Paper 6846, Cambridge, MA: National Bureau of Economic Research, December 1998.

13. Price Waterhouse Coopers, Eighth Annual Economic Impact of Venture Capital Study, November 1998.

14. Castle Placement. https://castleplacement.com/defensetechnology-industry-venture-capitalprivateequity/

15. The Army first software factory fuilly up and running. Establish an Effective Zero Trast Strategy.

URL: https://www.fedscoop.com/army-softwarefactory-austin.

16. Аарон Мехта "Математика не має сенсу»: Чому фірми венчурного капіталу насторожено ставляться до оборонних інвестицій". https://www.defensenews.com/smr/cultura I-clash/2020/01/30/the-math-doesnt-makesense-why-venture-capital-firms-are-waryof-defense-focused-investments/

17. The Army as Venture Capitalist: An Innovative Approach to Funding Research and Development. URL: https://www.rand.org/natsec_area/product s/vc.html

18. For a more detailed discussion, see Kenneth Horn, Elliot P. Axelband, Ike Yi Chang, Paul S. Steinberg, Carolyn Wong, and Howell Yee, Performing Collaborative Research with Nontraditional Military Suppliers, Santa Monica, CA: RAND, MR-830-A, 1997.

19. Стратегія розвитку обороннопромислового комплексу України, затверджена Указом Президента України від 20 серпня 2021 р. № 372/2021. URL: https://www.president.gov.ua/documents/3 722021-39733

\title{
Венчурное финансирование оборонной промышленности: опыт США в украинском измерении
}

\author{
Виталий Бегма * 1 А; Владимир Шемаев 2 А; Денис Радов ${ }^{3}$ в; \\ Полина Толок 4 с \\ Corresponding author: * 1 д.э.н., профессор, ведущий научный сотрудник, e-mail: vitnik1964@ukr.net, ORCID: 0000-0002-0556-1785 \\ 2 д.воен.н., профессор, главный консультант, e-mail: shemayeva@ukr.net, ORCID: 0000-0003-1629-6689 \\ ${ }^{3}$ к.э.н., докторант, e-mail: naukadradov@gmail.com, ORCID: 0000-0001-8139-4563 \\ ${ }^{4}$ Заслуженный экономист Украины, к.э.н., старший научный сотрудник, e-mail: tolok100@meta.ua, ORCID: 0000-0002-2481-8152 \\ А Национальный институт стратегических исследований, г. Киев, Украина

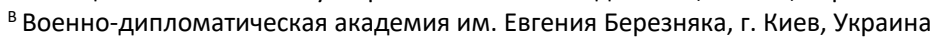 \\ с Центральный научно-исследовательский институт ВВТ ВСУ, г. Киев, Украина
}

\begin{abstract}
Аннотация
В статье проанализирован опыт США по использованию венчурного капитала при финансировании работ по развитию современных образцов вооружения и военной техники и технологий военного и двойного назначения. Исследования эффективности использования венчурного капитала в США подтвердили положительную корреляцию между венчурным капиталом и инновациями на использующих его фирмах. При этом отмечается высокий уровень патентной активности, а также большие инвестиции в исследования и разработки, которые эти фирмы делают по сравнению с другими компаниями. Раскрыты сущность, особенности и влияние венчурных инвестиций на инновационное развитие оборонной промышленности, ее вклад в экономическое развитие страны в целом. Основные преимущества использования венчурного капитала в интересах вооруженных сил в США состоят в следующем: венчурный капитал позволяет использовать невоенные ресурсы; обеспечивается возврат инвестиций и армия может
\end{abstract}


зарабатывать на окупаемости инвестиций по мере роста их коммерческого рынка; венчурный капитал помогает поднять целые отрасли.

Выявлены основные проблемы и тенденции венчурного инвестирования в оборонной сфере США: развитие сотрудничества между научно-исследовательскими подразделениями армии и разработчиками коммерческих технологий усложняют: традиционно сложная процедура заключения контрактов в армии, при этом, коммерчески-ориентированные компании считают размер армейского рынка небольшим с громоздкими правительственными правилами закупок, негибкие требования к надзору и опасения по поводу интеллектуальной собственности. Определены возможные перспективные сферы эффективного использования венчурного капитала для оборонной промышленности Украины. Для этого необходимо создать новую систему финансового, кредитного и инвестиционного обеспечения оборонно-промышленного комплекса, а также создать благоприятный инвестиционный климат для осуществления инвестиций в оборонно-промышленный комплекс, в частности, механизм защиты этих инвестиций с обеспечением национальных интересов и национальной безопасности.

Ключевые слова: венчур, капитал, инвестирование, фонды.

\title{
Defense Industry Venture Financing: US Experience in the Ukrainian Dimension
}

\author{
Vitaly Begma * 1 A; Vladimir Shemaev ${ }^{2}$ A; Denis Radov ${ }^{3}$ B; \\ Polina Tolok $4 \mathrm{C}$ \\ Corresponding author: *1 Doctor of Economics, Professor, leading researcher, e-mail: vitnik1964@ukr.net, ORCID: 0000-0002-0556-1785 \\ ${ }^{2}$ Doctor of Science, Professor, chief consultant, e-mail: shemayeva@ukr.net, ORCID: 0000-0003-1629-6689 \\ ${ }^{3}$ Ph.D., doctoral student, e-mail: naukadradov@gmail.com, ORCID: 0000-0001-8139-4563 \\ ${ }^{4}$ Honored Economist of Ukraine, Ph.D., Senior Researcher, e-mail: tolok100@meta.ua, ORCID: 0000-0002-2481-8152 \\ A National Institute of Strategic Education, Kyiv, Ukraine \\ B Military Diplomatic Academy named after Evgeniya Bereznyak, Kyiv, Ukraine \\ ${ }^{c}$ Central Research Institute of Military and Military Equipment of the Armed Forces of Ukraine, Kyiv, Ukraine
}

\begin{abstract}
The article analyzes the US experience in the use of venture capital in financing the development of modern models of weapons and military equipment and military and dual-use technologies. Studies of the efficiency of the use of venture capital in the United States have confirmed a positive correlation between venture capital and innovation in firms that use it. At the same time, there is a high level of patent activity, as well as large investments in research and development, which these firms do compared to other companies. The essence, features and influence of venture investments on the innovative development of the defense industry, its contribution to the economic development of the country as a whole are revealed. The main advantages of using venture capital for the benefit of the US military are as follows: venture capital allows the use of non-military resources; return on investment is ensured and the army can earn a return on investment as their commercial market grows; venture capital helps to lift entire industries.

Highlights the main challenges and trends of venture capital investment in the United States: Development of cooperation between military research units and developers of commercial technologies, government procurement rules, inflexible requirements for supervision and concerns about intellectual property. Possible promising areas for effective use of venture capital for the defense industry of Ukraine have been identified. To do this, it is necessary to create a new system of financial, credit and investment support for the defense industry, as well as to create a favorable investment climate for investment in the defense industry, in particular, a mechanism to protect these investments.
\end{abstract}

Keywords: venture, capital, investment, funds. 


\section{References}

1. Levkovich-Maslyuk L. Tochka rosi. [Dewpoint]. Biznes-zhurnal "Komp'yuterra». Available from: http://www.computerra.ru/compunity/femi $\mathrm{da} / 21747 /$

2. Polyak M. M. Suchasnyy stan ta perspektyvy rozvytku venchurnoho investuvannya $v$ Ukrayini. [The current state and prospects of venture investment development in Ukraine]. Derzhava ta rehiony. Ser. : Ekonomika ta pidpryyemnytstvo. 2013. no. 5. pp. 113-116. Available from: http://nbuv.gov.ua/UJRN/drep_2013_5_22.

3. Yakovets' H. YU. Napryamy udoskonalennya analizu venchurnoyi diyal'nosti dlya pryynyattya uprav-lins'kykh rishen'. [Directions for improving the analysis of venture activity for making management decisions]. Visnyk Zhytomyrs'koho derzhavnoho tekhnolohichnoho universytetu. Seriya : Ekonomichni nauky. 2015. no. 1. pp. 63-67. Available from: http://nbuv.gov.ua/UJRN/Vzhdtu_econ_201 5_1_11.

4. Koval'ova, O. M. Deyaki teoretychni ta praktychni aspekty obgruntuvannya vyboru dzherel fi-nansuvannya pidpryyemstva. [Some theoretical and practical aspects of substantiation of the choice of sources of financing of the enterprise]. Problemy rynku ta rozvytku rehioniv Ukrayiny $v$ XXI st.: materialy VII Mizhnarod. nauk.-prakt. Internet-konf., m. Odesa, 05-09.12. 2016 r. Odesa, 2016. Pp. 40-43.

5. Petruk O. M., Moshens'kyy S. Z. (2008). Teoriya ta praktyka venchurnoho finansuvannya. [Theory and practice of venture financing]. Zhytomyr: Ruta, 2008. 248 p. (in Ukrainian).

6. Poruchnyk A. M., Antonyuk L. L. (2000). Venchurnyy kapital: zarubizhnyy dosvid ta problemy stanov-lennya v Ukrayini. [Venture capital: foreign experience and problems of formation in Ukraine]. Kyiv: KNEU, 2000. 171 p. (in Ukrainian).

7. Klymenko V. V. Venchurnoe ynvestyrovanye: myrovoy opyt y Ukrayna. [Venture investment: world experience and Ukraine]. Naukovyy visnyk Instytutu mizhnarodnykh vidnosyn Natsional'noho aviatsiynoho universytetu: ekonomi-ka, pravo, politolohiya, turyzm. Tom, no. 1-2 (2012). 37$45 \mathrm{pp}$.

8. Buturlakina T. O., Zavats'ka V. V. Problemy funktsionuvannya venchurnoho kapitalu yak dzherela finansuvannya innovatsiynoyi diyal'nosti $v$ Ukrayini ta shlyakhy vdoskonalennya (na prykladi dos-vidu SSHA). [Problems of venture capital functioning as a source of financing innovation in Ukraine and ways to improve (on the example of the US experience)]. Hlobal'ni ta natsional'ni problemy ekonomiky. Elektronne naukove vydannya Mykolayivs'koho natsional'noho universytetu im. V.O. Sukhomlins'koho. No. 4 (2015). 791-784 pp.

9. Venture-backed Startups Will Build the Defense Technology the Free World Needs Right Now Josh Manchester, Jun 13, 2019. Available from: https://medium.com/@joshmanchester/ven ture-backed-startups-will-build-the-defensetechnology-the-free-world-needs-right-nowd2cefa2b2196.

10. Maksim Chebotarev. Investitsii poamerikanski: kak rabotayut venchurnyye fondy v SSHA. [Investing in American Style: How Venture Funds Work in the USA]. Forbes Contributor. 28.04.2018. Available from: http://www.forbes.ru/tehnologii/360888investicii-po-amerikansky-kak-rabotayutvenchurnye-fondy-v-ssha.

11. Venture Capital Funding Report Q4 2020. PwC and CB Insights' Q4 2020 Money Tree report highlights the latest trends in venture capital funding globally. 13.01.2021. Available from: http://www.cbinsights.com/ research/report/venture-capital-q4-2020/.

12. Samuel Kortum and Josh Lerner (1998). Does Venture Capital Spur Innovation. Working Paper 6846, Cambridge, MA: National Bureau of Economic Research, December 1998. 
13. Price Waterhouse Coopers, Eighth Annual Economic Impact of Venture Capital Study, November 1998.

14. Castle Placement. Available from: https://castleplacement.com/defensetechnology-industry-venture-capitalprivateequity/

15. The Army first software factory fuilly up and running. Establish an Effective Zero Trast Strategy. Available from: https://www.fedscoop.com/army-softwarefactory-austin.

16. Aaron Mekhta. Matematyka ne maye sensu: Chomu firmy venchurnoho kapitalu nastorozheno stavlyat'sya do oboronnykh investytsiy. [Mathematics doesn't make sense: Why venture capital firms are wary of defense investments]. Available from: https://www.defensenews.com/smr/cultura I-clash/2020/01/30/the-math-doesnt-make- sense-why-venture-capital-firms-are-waryof-defense-focused-investments/.

17. The Army as Venture Capitalist: An Innovative Approach to Funding Research and Development. Available from: https://www.rand.org/natsec_area/product s/vc.html.

18. Kenneth Horn, Elliot P. Axelband, Ike Yi Chang, Paul S. Steinberg, Carolyn Wong, and Howell Yee (1997). Performing Collaborative Research with Nontraditional Military Suppliers, Santa Monica, CA: RAND, MR-830A, 1997.

19. Stratehiya rozvytku oboronnopromyslovoho kompleksu Ukrayiny. [Strategy for the development of the defenseindustrial complex of Ukraine], zatverdzhena Ukazom Pre-zydenta Ukrayiny vid 20.08.2021 r. № 372/2021. Available from: https://www.president.gov.ua/documents/3 722021-39733. 